\title{
A Contextual Analysis of Riba under the Framework of Exchange
}

\author{
Revised Manuscript \\ 01-Jan-2022
}

Author:

Position:

Affiliation:

Email:

Phone:
Shahid Sultan

CEO

Attock Construction \& Finishing Services shahid.innovative@gmail.com

$+923355218171$ 


\title{
A Contextual Analysis of Riba under the Framework of Exchange
}

\author{
Contents

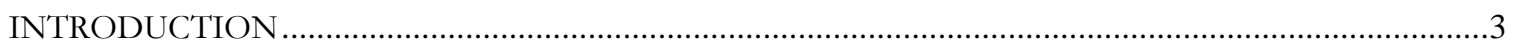

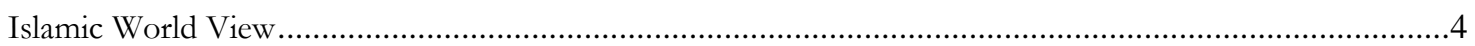

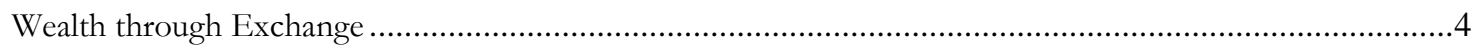

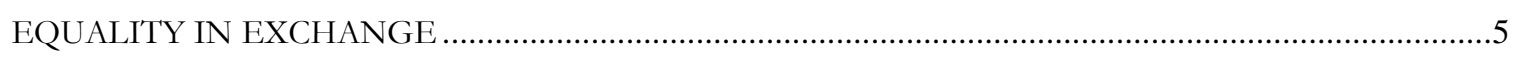

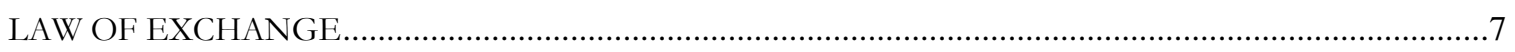

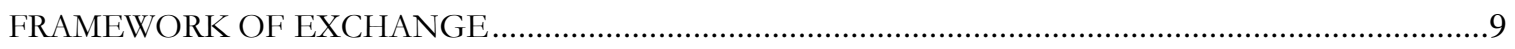



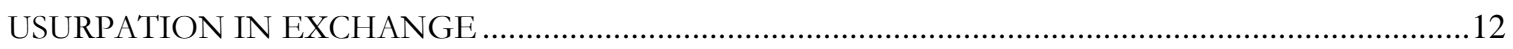

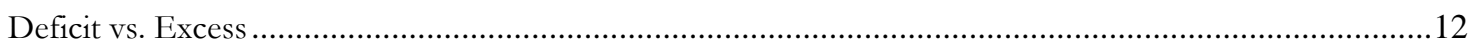

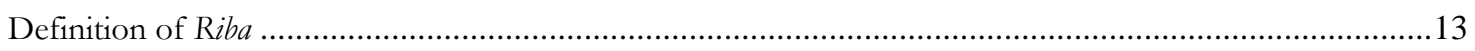

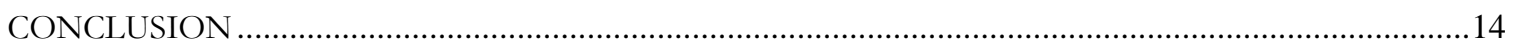

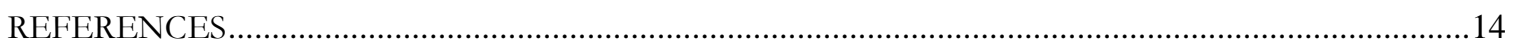

\begin{abstract}
In modern times, the prohibited excess or riba has attracted divergent opinions from scholars which are different from the ones in the pre-colonial era. This fact necessitates a clear understanding of riba by putting it into its proper context as against the efforts to understand it in isolation. The prohibition of riba points towards the existence of a concept of equivalent exchange and it is proven from the primary sources of Islamic law. Equivalent exchange is without excess or deficit caused by either party to each other or third parties. The guidance from the primary sources and legal literature reveals that riba is over and above an equivalent exchange and its manifestations are manifold. Primarily, these manifestations can be grouped as corporeal, incorporeal, and temporal. This article places the concept of riba into its larger context and compares and differentiates it from other components of the framework of exchange. Whereas profit and loss are the differences between two equivalent exchanges, riba and deficit are differences between unequal and equivalent exchanges. As per the definition of riba, the presence of excess over and above an equivalent exchange without counter-value renders the exchange unequal. The only form of exchange that is acceptable in Islam is an equivalent exchange, be it on the spot, credit, or a charitable financial accommodation.
\end{abstract}

Keywords: $\quad$ Exchange, equality, trade, riba, money, time

KAUJIE Classification: Q11, Q61, Q62, Q64

JEL Classification: $\quad$ B11, E42, K12, K42, P43, Z12 


\section{INTRODUCTION}

Despite having the central place in the discourse of Islamic Economic systems, riba (prohibited excess) has attracted divergent and sometimes contrasting descriptions in the post-colonial era. For instance, a survey of the literature reveals that modern scholars equate the prohibited excess of delay (riba al nasi'ab or nasa'a) to the interest received by the lender (Chapra, 2008, p.111; Haque, 1982, p. 35; Islahi, 2011, p.150; Siddiqui, 2004, p. 54; Usmani as cited in Suharto, 2018, p.134; Zaman, 2009, p. 4; Zahra and Mawdudi as cited in Nyazee, 2009, pp. 24-36; Zuhayli, 2006). Whereas, Nyazee (2009) and Siddiqui \& Ahmad (2019) have shown that according to the leading authorities of Islamic jurisprudence in the pre-colonial era, the recipient of riba al nasa'a is the borrowing party. The same understanding has been given by Qazi Muhammad Sanaullah Panipati (2002, p.563 $\& 567)$, a leading jurist of the $18^{\text {th }}$ century in India ${ }^{1}$.

In the above perspective, it is important to clarify the concept of riba in a way that takes into account its original understanding as well as the framework or context in which it arises. Such an explanation is important because in the post-colonial era almost all states governed by Muslims have adopted capitalism as their de facto economic system in which commercial banking plays a central role. Thus, the central question that how the interest charged by modern commercial banks relates to the prohibited riba requires a rational \& holistic answer. In addition to this, the clear understanding of riba may also help in the settlement of the controversy about the practical feasibility of Islamic banking models that is frequently put into perspective by researchers, for example, by Gulzar, Ibrahim \& Ariff (2020), Siddiqui \& Rashid (2019) and Shah \& Niazi (2019).

This article aims at placing the concept of riba into its proper context and tries to answer common sense questions such as if riba means prohibited excess then what are the features of the exchange that does not carry this excess? What would be the nature and status of "deficit" in contrast to riba? What is the nature and status of profit and loss, which are also excess and deficit for the trader respectively? What is the defining feature of riba? Who is the recipient of riba? Borrower, lender, seller, or buyer? Thus the purpose of the article is to clarify the concept of riba inside a framework while taking guidance from the latest discussions in Islamic Law (Shari'ah).

The article is structured in a logical flow of ideas leading up to the definition of riba. It starts by giving a brief description of the Islamic worldview and concept of wealth after which equivalent exchange and the law

\footnotetext{
${ }^{1}$ Qazi Muhammad Sanaullah Panipati (1730-1810) was the student of Shah Waliullah Dehlvi and Mirza Mazhar Jan e Janan. His most famous contribution is his exegesis of the Qur'an "Tafseer-e-Mazhari” named after his spiritual teacher. He was called "Baheqi" of the time by Shah Abdul Aziz Dehlvi. He followed principles of tafseer laid down by his teachers. He resolved, differed from earlier opinions, did ijtihad and presented his research on many issues after detailed analysis.
} 
of exchange are explained in detail. The discussion leads to the layout of the framework of exchange followed by the conception and definition of riba. The scope of this article is limited and further discussions and applications of the understanding developed on the historical developments and current state of riba have been left for another follow-up article.

\section{Islamic World View}

Allah is the creator of all the wealth of the heavens and earth and is the Owner of everything. He created human beings as His vicegerent (khalifa) on this resourceful and sustainable earth to test (Q. 8:28, 2:36, 30:41) if they follow His Messengers and accept His obedience or instead follow ego (nafs) and satan. Thus, no human being is an absolute owner of wealth but only relative to fellow human beings. This is the reason that after the death of a person, his / her unconsumed wealth is divided among the heirs and the corpus is returned to the earth.

The wealth in this world takes on different forms; organic or inorganic, with or without life. It is mainly composed of matter and energy while the production and services of humans or a machine are the results of a combination of both. Wealth is distributed throughout the world, just like human beings. Neither it has been created nor it is lying idle but at the service of humankind (Q. 45:12-13).

Scholars of the Qur'an have identified the phased development of the progeny of Adam (AS). According to them, humanity was in its childhood until Prophet Noah (AS), in youth until Prophet Moses (AS), in middle age until Prophet Jesus (AS) and in its old age when Prophet Muhammad (PBUH) arrived as the last and final Messenger of Allah for all the ages to come (Khan, n.d.; Q. 6:6, 9:69, 19:74, 28:78, 30:9, 33:40). Wisdom, cleverness, weakness, greed, and diseases generally characterize old age and so are in abundance in this old age of humanity. With this background in mind, we proceed and try to understand the ideal and the contemporary status of the institution of exchange as it is before our eyes.

\section{Wealth through Exchange}

By revealing it to the Prophet (PBUH), Allah gave His verdict about the manner of distribution of wealth among human beings. He says in the Qur'an (4:29);

O, believers! Do not devour the property of one another among yourselves unjustly. Yes, (there is no harm) if you trade among yourselves with mutual agreement. And do not kill (one another) among yourselves; without doubt, Allah is Extremely Merciful to you. 
Humans first engaged themselves in agriculture (which requires no factory or raw materials), livestock (domesticizing the animals), and hunting (direct acquisition) for the fulfillment of their basic needs with the guidance of Allah (Q. 2:164, 5:4, 36:71). He then prescribed the method of exchange to acquire a property that is wanted by parting with a property that is wanted by others. Besides, He prohibited the acquisition of property that belongs to others, in ways and means contrary to the injunctions and objectives of Shari'ah.

It ultimately resulted in the profession of trade (tijarah), which was necessary because of the diversity in human possessions, skills, distances, and investment involved in acquiring the needful. The reward for fulfilling the needs of fellow human beings at the right time and the right place was profit, which is the excess earned in the process of trade. It must be noted that Allah is the Sustainer ( $A r$ Rabb); the One who fulfills all the needs of all creation, all the time and at all places (Awan, 2013, III, p. 259). Thus, the profession of trade is a sacred duty, to be fulfilled as a true vicegerent of Allah as much as possible (Q. 57:7).

However, it must also be remembered that despite all the efforts, abilities, opportunities, and strategies employed by human beings, Allah withholds or gives plentifully to His slaves as part of the test for which they were sent into this world (Q. 2:245, 28:78, 30:37, 43:32; Saleem, 2013, p. 16).

\section{EQUALITY IN EXCHANGE}

Just as the idea of earning a livelihood through an exchange of commodities, products, human work, and property-usufruct is rooted in the very instinct of human beings, so is the expectation of fair treatment, through an equivalent exchange (tabadla masaam). The prime reason for this expectation is the equivalence of humans in the right to keep life and property. Therefore, an equivalent exchange is without excess or deficit, caused by either party to each other or the third parties ${ }^{2}$ (Figure 1). Allah has made it obligatory (fard) upon Muslims to observe equivalence in the benevolent loan (qard) and sale (bay) in the verses of prohibited excess (riba) in the Qur'an $(2: 275,276,278,279,3: 130,4: 161)$ and the commandment is comparable and manifests in the following verse (Panipati, 2002, I, pp. 548-549). Allah says in the Qur'an (2:194)

"The sacred month is for the sacred month, and sacredness is reciprocal (to each other); therefore, if someone transgresses against you, you may transgress against him only to the extent of his

\footnotetext{
${ }^{2}$ This statement is the author's overall understanding and shall get explained along the article and in the section framework of exchange.

${ }^{3}$ Panipati (2002) after detailed analysis of all four schools position on the nature of riba gives his learned opinion (and differs from earlier fuqaha on the matter) that the term riba is not unelaborated (mujmal). It is elaborated within the Qur'an.
} 
transgression. And remain conscious of Allah, and know well that

Allah is with those who are conscious of Him."

Panipati (2002) interprets that according to the above verse if someone causes a loss to a homogeneous (mithli) property of another person then the other person has a right to receive restitution in the shape of property that is equivalent; corporeally (surattan) by weight or volume, as well as incorporeally (ma'anmi), that is, it must be from the same species (pp. 548-549). But in case the lost property was distinctive (ghair mithli) then its incorporeal equivalent, which is the market price (thaman) in the shape of money (naqd), shall be given because explicit corporeal equivalence by weighing, for example, is not possible (pp. 548-549).

Panipati (2002) further elucidates that the same rule applies to the sale or commercial exchange (bay) as well (due to equal level of formality) (pp. 548-549). If the properties to be exchanged belong to the same species, that is, they are incorporeally equivalent, then upon application of the general rule of equivalence of exchange they must be equated corporeally as well, in terms of weight, for example (pp. 548-549). It also follows by analogy that both properties shall be exchanged simultaneously, again, to follow the general rule of equivalence in letter and spirit. Whereas in the case of a non-comparable property, its incorporeal equivalent, that is, the price shall be given as counter-value with mutual consent (pp. 548-549).

The major difference between the restitution and sale would be in the determination of the incorporeal equivalence of the counter-values. In the case of restitution, a capable third party will decide, what is equivalent, keeping in view justice because the parties had not agreed on equivalence before the event of loss occurred (Panipati, 2002, I, pp. 548-549). Whereas in the case of a sale, parties to the exchange give their verdict of equivalence of counter values with mutual consent before the event of the exchange, and therefore their judgment regarding their properties shall be considered enough and will take precedence over third party judgment or evaluation (Panipati 2002, I, pp. 548-549).

Islam has guided human beings about the rules and norms of market places, the standardized intermediary property of money, formalities of agreement, expression of mutual consent, and post exchange options \& facilities (Saleem, 2013) to the exchange so that they can objectively pass the judgment of incorporeal equivalence within the session of exchange. 


\section{LAW OF EXCHANGE}

Prophet (PBUH), by the will of Allah and based on the knowledge inspired by Him (Q. 53:3-4), articulately delineated the Qur'anic prohibition of riba and the obligation of equality in exchange in the following hadith and other similar traditions (ahadith).

From 'Ubadah ibn al-Samit, who said, "The Messenger of Allah (God's peace and blessings be upon him) said, 'Gold for gold, silver for silver, wheat for wheat, barley for barley, dates for dates, salt for salt, like for like, in equal weights, and from hand to hand. If these species differ, then, sell as you like, as long as it is from hand to hand." ${ }^{4}$ Reported by Muslim.

The above hadith makes it obligatory upon Muslims to observe equivalence in exchange as a general rule; and specifically, it prohibits excess in the exchange of a homogenous species with itself in terms of measurement or time of possession of counter values regardless of any quality (jawda) difference or a need of delay. For instance, dates of higher quality are not allowed to be sold for a higher weight of inferior quality. Similarly, it is also not allowed to deliver lower quality dates on the spot against higher quality dates in equal weight in the future. The reason is that the quality is only an attribute (wasf) and quality difference within species is a subjective opinion whereas similarity of species is an objective fact. Similarly, the equivalence that is logically and automatically proven in spot exchange of similar species breaks down once either or both counter values are delayed for possession (Panipati 2002, I, pp. 548-549). For instance, a counter value that is delivered on spot is higher in value than the one that has been delayed (Panipati, 2002, pp. 548-549). Hence, no permission has been given in Shariah for use of any valuation method or market-based exchange ratio for the determination of the value of quality difference or delay in a direct exchange to eliminate any chance of opening of a door to riba. However, to fulfill the corporeal need, for example, the low-quality dates may be sold for a price and the proceeds may be used to buy high-quality dates (Panipati 2002, I, pp. 548-549). Similarly, to provide for capital, an agency or sharing agreement may be signed between the parties.

\footnotetext{
${ }^{4}$ The reader will be surprised to see that this hadith and other similar traditions are the direct explanation of the above quoted verse (Q. 2:194). This also proves that the segregation created by modern scholars by coining the terms of riba al Quran and riba al Hadith is a false dichotomy.

5 Thus, the Islamic concept is not limited to "Time value of Money" but it acknowledges time value of counter value. This is the reason a higher price in the credit sale than the spot price is allowed. Whereas, in case of same thing on both sides the excess time value causes the already established equivalence to break down and is termed as riba al nasi'ah. This resolves the long standing controversy amoung modern scholars wheather or not accept the time value of money concept.
} 
Thus, the first and foremost inference from the above hadith is that the prohibited excess or riba is of two fundamental kinds; one that can be estimated or residual named as riba al fadl and time delay named as riba al nasi'ah. Secondly, the prohibited excess (may it be in any form) is always over and above an already equivalent exchange without a counter value.

The above general rule of equivalence in exchange shall be applicable incorporeally (through the application of mutual goodwill and ascent (Q. 4:29)) when the species are different yet from the same genera, for example, gold against silver. Whereas the rule of temporal equivalence (that was only an analogy under the explanation of verse 2:194 in the last section but became a definitive rule in the hadith), that is, immediate exchange, shall still be applicable due to certain major similarities between the counter-values (as per legal criterion) such as homogeneity, the similarity of genera, the scale of measurement, etc. Thus, credit sale has been prohibited in it for the same reasons as in the case of an exchange of the same species.

However, in the case of an exchange of different genera, for example, a goat for a dinar of gold, a period of delay in the payment of price can also be agreed upon and it shall not be riba al nasi'ab ${ }^{6}$. The reason for it is that in the case of different genera, the equivalence does not arise automatically or naturally (by the interaction of counter values) and it establishes only when the counterparties interact and give their verdict of equivalence of their respective counter values in the session of exchange. Therefore, they can agree on any price of credit sale keeping in view the payment schedule. Thus, the price that is agreed shall be a complete counter value for the value received as well as the facility or feature of delay in payment. It follows that the credit period must be fixed because otherwise, it may lead to dispute as the price cannot be increased once the sale is concluded and incorporeal equivalence is established (Q. 2:282). Therefore, an incorporeally equivalent credit sale shall be considered as if gold or any other homogeneous commodity has been exchanged for itself in equal weight on the spot. Thereafter, the creditor is not allowed to ask for an increment against an extension in time of the due debt of credit sale and the debtor is not allowed to buy time against any increment in price or any other benefit to the creditor or a third party.

Another important implication of the above hadith stems from the fact that all the commodities mentioned therein are homogeneous (mithli) and therefore qualify for the valuation of distinctive goods and services in the form of a quoted price. Additionally, the gold and silver that have been mentioned first in the hadith have remained money proper during much of human history and are still considered the same by many.

\footnotetext{
${ }^{6}$ However, if the price is paid on spot for a future delivery of goat then it is not allowed by the Shari'ah as a rule because the subject matter must be present for determination and possession. Exception to this rule is bay' salam.
} 
Whereas the remaining commodities can be labeled as near money and their usage can be traced as payment in the near past.

It follows that no Muslim is allowed, under commercial settings (as indicated by the words "sell"), to take ownership (exclusive possession with the right of disposal) of money or absolute price (thaman) from another person without giving back equivalent counter value within the session of exchange. Similarly, the delay in such an exchange is prohibited for both side parties as indicated by the words "from hand to hand." The detailed rules are found in the model contract of bay' sarf that deals with the exchange of currencies. It must also be noted here that in the case of similar species the meaning of the words "hand to hand" would be to simply return the value received and abandon the exchange without any damage caused but in the case of different species, a reciprocal exchange is possible on the spot for a benefit. Another important implication of hadith is that the directive contained within the hadith is positive, that is, it instructs Muslims to engage in equivalent exchange; the result of that would be abstention from prohibited excess of all kinds, regardless if we are aware of them all or not.

In the context of the above inferences from hadith, it is important to note that under commercial settings, lending money is equivalent to selling money, and borrowing money is equivalent to buying money (Nyazee, 2009, p.50; Siddiqui \& Ahmed, 2019, p. 180; Panipati, 2002, p. 567). Also, the riba is thus of two kinds, riba al fadl, where estimation ( $q a d r$ ) is possible and time delay (riba al nasa'a) (Al-Ghazali, Al-Jassas, Al-Kasani, AlSarakhsi as cited in Nyazee, 2009, pp. 42-71; Khalil, 2006, p.56; Siddiqui \& Ahmed, 2019). In a commercial monetary debt, for example, the lender (seller) is the beneficiary of quantifiable or estimated excess, which is "interest" (measurable due to its flow from one party to another) whereas the beneficiary ${ }^{7}$ of time delay is the borrower (buyer) (Nyazee, 2009, p. 113; Siddique \& Ahmed, 2019, p. 189). Here, it should be noted that riba al fadl is not limited to the excess of the same commodity by weight or volume in an exchange. One can very easily infer after reviewing authentic traditions regarding riba that manifestations of riba are manyfold. The above-quoted hadith regarding six commodities also does not put a limit to the manifestations of riba but provides the foundation stone for the theory of equivalent exchange in Islam.

\section{FRAMEWORK OF EXCHANGE}

When gold is exchanged against gold in equal quantity on the spot, then keeping in view Figure 1, there shall not be any profit, loss, utility, or wastage as well as no prohibited excess and no prohibited deficit as a result.

\footnotetext{
${ }^{7}$ The impermissibility of riba al nasi'ah that benefits the borrower also proves that any kind of excess that is over and above the equivalent exchange favoring any side party is prohibited, be it in the form of money, property or an incorporeal benefit.
} 
However, the moment one side delays the possession of gold beyond the session of exchange; temporal excess (riba al nasa'a) shall arise before even the question arises of any profit, loss, utility, wastage, or interest. Thus, the very idea of commercial monetary debt or a market for loanable funds is non-existent in the Shari'ah, ab initio (Siddique \& Ahmed, 2019) ${ }^{8}$.

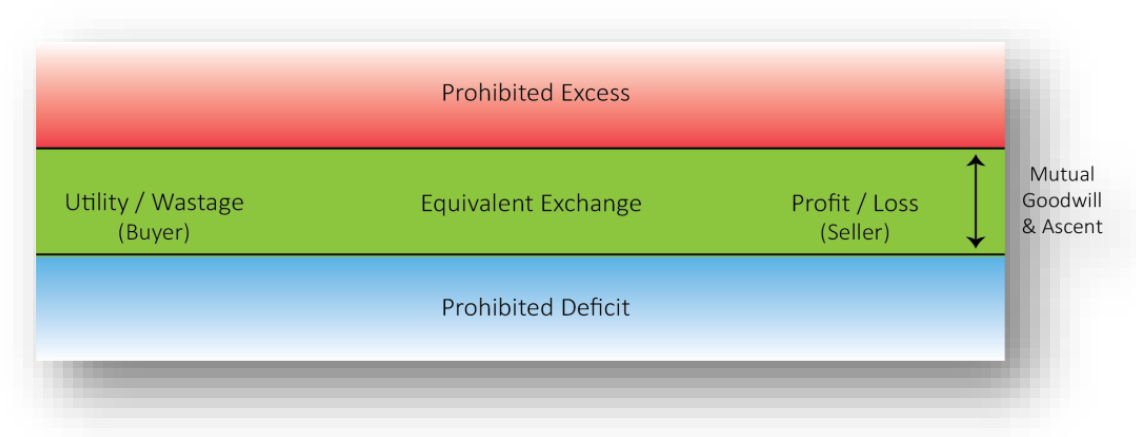

Figure 1. Framework of Exchange

The lawful opportunity of profit arises when a trader exchanges two distinctive species from the same genera or different genera due to the existence of several exchange ratios or rates. And a difference between the two exchange ratios of buying and selling may result in profit or loss for the trader. For example, a trader may exchange 4.25 grams of gold for 16 grams of silver in one transaction and 5.25 grams of gold for 16 grams of silver in a subsequent transaction, thus turning a profit of one gram of gold. Similarly, the trader can incur a loss as well in the same way. Therefore, no lawful opportunity of profit exists while exchanging a species for itself in two or whatever number of transactions.

Additionally, the seller or the buyer cannot attribute the source or cause of profit or loss to the counterparty in the absence of any specific claim. For instance, a seller will incur a loss due to exogenous factors, for example, a fall in price in the market or higher than expected costs incurred or accrued, etc. However, he/she cannot claim that the purchaser caused the loss in the presence of mutual consent and the absence of any defect in payment. Similarly, the cause of wastage or the presence of profit cannot be attributed to the seller in the presence of mutual consent and the absence of any defect in the goods or services provided.

Therefore, the profit and loss are the differences between two equivalent exchanges (buying and selling) and they result in the trader (Figure 1). Their causes are operative prior to the session of exchange while their

\footnotetext{
${ }^{8}$ However, qard which is a non-commercial accommodation is allowed by the Shari'ah as an exception to the rules of riba with its own limits, conditions and recommendations. It shall be discussed in the follow up paper.
} 
level is determined in the negotiations of exchange. On the other hand, utility and wastage result in the buyer or end consumer. Their causes are operative subsequent to the session of exchange and their level is determined during the period of utilization.

\section{Countervalues of Exchange}

Al-Sarakhsi (as cited in Nyazee, 2018) defines legitimate commercial exchange (bay' halal) as an exchange of marketable wealth (mal e mutaqawmim) against marketable wealth. Additionally, the Shari'ah recognizes a nonbarter market system where money plays a vital role in price discovery. Therefore, marketable wealth in the Shariah is of two fundamental kinds; one that is the objective (maqsood biz'at) of an exchange transaction or subject matter ('ayn or mobeeb) and the one that is a means of acquisition of the objective, that is, money or naqd (Panipati 2002, I, pp. 548-549).

Also, in the eyes of the Shari'ah any property or wealth that is homogeneous and can be weighed, measured, or consists of identical units which simply require a count and determinable in absentia just by mentioning, is akin to money in addition to money proper which are dirhams and dinars made of gold and silver'. Thus, commercial exchange (bay') has been divided into four categories in the Shariah; sale of a subject matter for money which is called an absolute sale, sale of a subject matter for a subject matter where both are distinctive and known as barter, sale of money for a subject matter which is called salam, and sale of money for money which is called sarf. The obligation of equivalent exchange in the Qur'an and Hadith encompasses all of the above kinds.

Money has been a necessary part of the trade since the young age of humanity and was developed as a standardized property having a stable intrinsic value that is enhanced to the level of liquidity by standardizing its unit weight, shape, size, and stamp, etc. As those units only require a count, thus prices were quoted in them of all goods and services in the market, a polity or geography (Q. 12:20). Humans extracted and utilized several items for this purpose and finally settled on precious metals, as the prime form of money for their quality of stable supply and value in addition to several other features (Meera, 2018, 2006).

However, the purpose of money remained the same, from the beginning until the rise of capitalism in the middle of the last millennium in Europe, which was to reveal market prices of everything through holistic valuation, where everything is compared with every other thing continuously in the market place after being

\footnotetext{
${ }^{9}$ Panipati (2002, p. 545) has differed from the Hanafi position which holds that when both counter values are homogeneous then one will be assumed as subject matter and the other as price. He asseted that the position is weak in front of hadith of six commodities and both commodities shall be considered prices for immediate possession in the session of exchange.
} 
exchanged or valued against a single property that is money by the market participants. It acted as a commonly accepted property for the valuation and pricing of distinctive properties to objectively establish incorporeal equivalence in real trade.

It should be noted here that the standardized property of money was acceptable just by mentioning its units in the contract of trade (incorporeal equivalence) and did not require an inspection or presence as required for the subject matter. Thus, it used to get attached to the responsibility (dhimmah) and therefore called debt (dayn) in the Shari'ah (Nyazee, 2018). Whereas, the money currently in circulation around the world consists of liabilities of central and commercial banks and is produced at the time of lending (Mcleay et al., 2014; Pforr \& Murau, 2020; Tymoigne, 2014) through the forward sale of monetary values where both counter values are delayed (and never paid). The liability of the bank becomes currency in the form of account balance or a printed note against the obligor's liability to adjust the same with increment at a future date. A detailed analysis of bank liability money shall be carried out in the follow-up paper. In this context, it has been concluded by several scholars over time that the property regarded as money in the Shariah is gold and silver (Al-Ghazali as cited in Nyazee, 2009, p. 65; Abdullah, 2020; Krichene \& Ghassan 2019; Meera, 2006).

\section{USURPATION IN EXCHANGE}

However, some human beings, out of temptations of ego and satan, occasionally show their disagreement with the distribution carried out by Allah and while going against the above-cited verdict (Q. 4:29), proceed in several ways to acquire the wealth that is not theirs as per the law of the Sustainer. First, they engaged themselves in plundering, banditry, and extortion but after having experienced the fact that outright appropriation and usurpation leads to utter hostilities and poses severe risks to their own lives and limbs, they contemplated and proceeded to attack the very institution of exchange, which was meant to distribute wealth with reciprocated goodwill and assent. The problem at the hand was intricate because a party from among two parties or both parties in collusion while exercising free will may not be able to expropriate wealth from each other or third parties at the same time.

\section{Deficit vs. Excess}

Given the above difficulty, some criminal traders made themselves content with exchange crimes which were related to the real counter value, that is, the good or service and whose objective was to inflict deficit by weighing less (Q. 11:84-85), hiding defects, distorting facts about the product (Al-Ghazali, n.d., pp. 128-134) and corrupting the measures \& scales. Others who prized excess income, resorted to fraudulent tactics and conspiracies aimed at extraction of increment over and above the level of profit that was coming from an 
otherwise equivalent exchange. For example by granting an extension to a due debt of credit sale against an increment by the creditor. Yet some others (money lenders and bankers) adopted the usurpation of wealth through the exchange as a distinctive profession while leaving the hassle of earning a profit aside. A detailed discussion of these developments shall be carried out in the follow-up article.

Therefore, the deficit or excess is the difference between a non-equivalent exchange and an equal one (Figure 1). In other words, the prohibited excess is over and above the equivalent exchange. Although the fact is that both of them have been condemned in the Qur'an and Hadith, the severity of the crime of causing excess is higher than causing the deficit as per textual evidence (Q. 275, 278-279).

\section{Definition of Riba}

Riba has been defined in the Shari'ah as "excess ( $f a d l$ ) without a (lawful) counter value, stipulated in reciprocal exchange (bay')" (Al-Sarakhsi as cited in Nyazee, 2018). In this definition, the word excess implies excess by way of estimation (corporeal or incorporea $1^{10}$ as a one-sided residual benefit) as well as by way of delay or time (temporal). While the word stipulation is in the sense of intention or a condition, which is either, concealed or expressly mentioned (or imposed) in the contact. Such as in the case of a creditor demanding excess against extension in debt agreed pre-facto or granted post facto. The word lawful indicates that excess cannot be claimed against unlawful or illogical counter value, as it is in the case of interest that is labeled as compensation for the period of delay provided where the delay (temporal excess) is itself illegal and illogical in the first place. Besides, this definition implies that a right and just trade would be equivalent, having no part, concealed or expressed, on spot or credit, without a counter value ${ }^{11}$. However, voluntary favor such as a discount can be given in the commercial exchange by the trader as well as by the buyer and that would be courtesy (Ihsan) (Al-Ghazali, n.d., pp. 135-148).

The definition also implies that the riba-eating trader can make money out of nothing. Meaning the excess benefit that he/she acquires through deceit or collusion with the counterparty is for him as if coming out of nothing, say from an empty basket; or in other words, risk-free. This is against trading where chances of profit and loss are balanced and gambling where chances of profit are minimal and those of the loss are maximum

\footnotetext{
${ }^{10}$ An incorporeal excess can take different forms such as a covenant in the contract which is not called for yet carries a onesided benefit. Panipati (2002, p.552) asserts that the commandment of Allah "And He has prohibited riba" (Q. 2:275) encompases any kind of benefit that is over and above an already equivalent exchange. For a very detailed and unique of its kind discussion regarding un-called for covenant in bay', see Panipati, 2002, pp. 551-555.

${ }^{11}$ A misconception amoung advocates of interest is that the implicit meaning of above definition is that riba can be undone by providing a value to countervalue that has been devoided of it. Thus, interest is a countervalue for the time period. Whereas the fact, as per Hanafi view, is that the transaction of sale becomes lawful by removing the riba, not by providing a countervalue to it. This is why the very concept of commercial monetary debt ceases to exit when delay (nasi'ah) is removed.
} 
(Awan, 2013, III, p. 98). Perhaps the reason behind the unmatched condemnations of riba, both in the Qur'an and Hadith (as cited in Chapra, 2008) is that it spoiled the sanctity of the institution of exchange; the natural way for the generation of permitted (halal) livelihood for masses and the primary way of the distribution of wealth by Allah.

\section{CONCLUSION}

Equality of all human beings in life and property necessitates equivalent exchange in which a party does not benefit at the expense of counterparty or third parties. The excess that has been prohibited by the Shari'ah and termed as riba for identification is a value, period, or benefit that is over and above an equivalent formal exchange. The presence of riba in real trade transactions negates the very purpose for which the trade has been recommended by Allah, that is, the prevention from mutual usurpation (Q. 4:29). Similarly, the purpose of the impermissibility of outright mutual usurpation agreements such as commercial monetary debt promotes justice through the equivalent exchange, liberty through the elimination of unlawful debt, and equal opportunity through freely operating real markets. It ensures the full and final settlement of each exchange transaction in real terms while blocking the exposure of the market and participants to excessive uncertainties, financial risk, and bankruptcies. It also ensures a just distribution of wealth, market transparency, and stable prices. The non-existence of financial (or monetary) markets promotes the circulation of wealth in the real sector that is the only available venue for earning a livelihood and wealth by the rich and poor alike. Despite the existence of no logical, textual, or historical proof for the validity and acceptability, the triumph of riba on the world stage can only be correlated with the victory of criminal traders during and after the colonial age. Thus, the way forward is the promotion of equivalent exchange, abstention from dealing with the financial industry, and efforts to affect policy-level decisions of at least the Muslim governments.

\section{REFERENCES}

Abdullah, A. (2020). The Islamic monetary standard: The dinar and dirham. International Journal of Islamic Economics and Finance Studies 2020(1), 1-29. doi: 10.25272/ijisef.659330

Awan, M. A. (2013). Akram Ut Tafaseer. Township, Lahore, Pakistan: Awaisia Kutab Khana.

Chapra, M. U. (2008). The nature of riba in Islam. Millah, 8(1), 107-121.

Al-Ghazali, A. H. M. (n.d.). Ibya Ul Uloom Ud Din: Vol. 2. (M. N. Al-Wajidi, Trans.). Karachi: Dar Ul Isha'at.

Gulzar, R., Ibrahim, M., \& Ariff, M. (2020). Are Islamic banks suffering from a model misfit? Comparison with cooperative banks. Journal of Islamic Monetary Economics and Finance. 6(2). doi: 10.21098/jimf.v6i2.1086 
Haque, Z. (1982). The nature of riba al-nasi'a and riba al fadl. Islamic Studies, 21(4), 19-38.

Islahi, A. A. (2011). An investigation into the relation between riba'l-Qur'an and riab'l-Hadith. In A. Ahmad \& A. A. Islahi (Ed.), Economic problems and the teachings of the Qur'an (pp. 141-161). Aligarh: Idarah Ulum AlQur'an

Khan, M. A. Y. (n.d.). Aqaid e shea, zabry bait ki zaroorat, wazaif. [Audio]. Retrieved from http://www.naqshbandiaowaisiah.com/audios/audio/Hazrat \%20Jee\%20Rua/mp3/

Khalil, E. H. (2006). An overview of the Shariah prohibition of riba. In A. Thomas (Ed.), Interest in Islamic Economics (pp. 53-67). New York: Routledge.

Krichene, N. \& Ghassan, H. B. (2019). The pre-eminence of gold and silver as Shariah money. Thunderbird International Business Review 61(5), 821-835.

Mcleay, M., Radia, A., \& Thomas, R. (2014). Money creation in the modern economy. Bank of England Quarterly Bulletin 54(1), 14-27.

Meera, A. K. M. (2018). Cryptocurrencies from Islamic perspective: The case of bitcoin. Bulletin of Monetary Economics and Banking. 20(4), 475-492. doi: 10.21098/bemp.v20i4.902

Meera, A. K. M. \& Larbani, M. (2006). Seigniorage of fiat money and the maqasid al-Shariah: The compatibility of gold dinar with the maqasid. Huminomics. 22(2), 84-97.

Murphy, J. B. (2002). Equality in exchange. The American Journal of Jurisprudence. 47(1), 85-121. doi: 10.1093/ajj/47.1.85

Nyazee, I. A. K. (2009). The prohibition of riba elaborated. Rawalpindi: Federal Law House.

Nyazee, I. A. K. (2018). Money exchange, loans and riba. Rawalpindi: Federal Law House.

Panipati, Q. M. S. (2002). Tafseer e Mazhari: Vol. 1. (M. M. Bostan, S. M. I. Shah, M. A. Maghalvi Trans.). Lahore: Zia Ul Qur'an Publications.

Pforr, T. \& Murau, S. (2020). What is money in a critical macro-finance framework? Finance and Society. 6(1), 56-66. doi: 10.2218/finsoc.v6i1.4409

Saleem, M. Y. (2013). Islamic commercial law: Ch. I. Singapore: John Wiley \& Sons.

Shah, B. A. \& Niazi, G. S. K. (2019). Issues in contemporary implementation of murabahah. Turkish Journal of Islamic Economics 6(2), 1-24.

Siddique, M. Z. \& Ahmad, M. M. (2019). Demystifying riba through the methodology of Muslim jurists. Islamic Studies 58(2), 169-203.

Siddiqi, M. N. (2004). Riba, bank Interest and the rationale of its probibition. Jeddah: Islamic Research and Training Institute. 
Siddique, M. A. \& Rashid, A. (2019). The fatawa in Islamic Banking and Financial Industry: Explaining the use of darurah (dire necessity) and hajah (need) maxims. Journal of Islamic Business and Management 9(2), 355367. doi: $10.26501 /$ jibm/2019.0902-008

Suharto, U. (2018). Riba and interest in Islamic finance: semantic and terminological issue. International Journal of Islamic and Middle Eastern Finance and Management 11(1), 131-138. doi: 10.1108/IMEFM-08-2016-0109

Tymoigne, E. (2014). A financial analysis of monetary systems. In D. B. Papadimitrious (Ed.), Contributions to economic theory, policy, development and finance: Essays in honor of Jan A. Kregel. (pp. 88-116). New York: Palgrave Macmillan. doi: 10.1057/9781137450968

Zaman, M. R. (2009). Usury (riba) and the place of bank interest in Islamic banking and finance. The International Journal of Banking and Finance 6(1), 1-15. doi: 10.32890/ijbf2009.6.1.8379

Al-Zuhayli, W. (2006). The juridical meaning of riba. In A. Thomas (Ed.), Interest in Islamic Economics (pp. 2552). New York: Routledge. 